Helle Lykke Nielsen er lektor, ph.d. på Center for Mellemøststudier ved Syddansk Universitet og fagansvarlig for centrets arabiskuddannelser. Hun arbejder pt. på et forskningsprojekt om det arabiske sprogs status og funktion $i$ Danmark, herunder især de sproglige landskaber på kirkegårde og begravelsespladser, i forretningskvarterer og som politisk og religiøs graffiti i storbymiljøer.

\title{
DET SIDSTE HVILESTED \\ Om tilhørsforhold og identitetsdannelse blandt muslimer i Danmark
}

Et stigende antal muslimske indvandrere og flygtninge vælger i dag at blive begravet i Danmark. Artiklen analyserer deres valg af sidste hvilested på henholdsvis en traditionel og en kommunal kirkegård samt på Danmarks eneste muslimske begravelsesplads i Brøndby, og indkredser derigennem en række markører, der kan udsige noget om identitetsdannelse og tilhørsforhold til den danske majoritetskultur. Analysen indkredser to tendenser i muslimsk begravelseskultur, henholdsvis en sakraliserings- og sekulariseringstendens, som kommer til udtryk der, hvor muslimer har et reelt valg mellem flere begravelsespladser. Det konkluderes, at muslimer i Danmark i al stilhed er i færd med en territorialiseringsproces, der foregår helt uden den turbulens, som ellers ofte præger den offentlige debat om muslimske indvandrere.

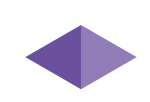

$\mathrm{M}$ uslimske begravelsespladser er i offentligheden mest kendt som konfliktstof på linje med debatter om moskeer, tørklæder og andre islamiske markører, som de seneste 30-40 års muslimske indvandring til Danmark har ført med sig: Fra midten af 1990'erne og frem til 2004 bølgede debatten om muslimers ret til egen begravelsesplads frem og tilbage i medierne. Den ophørte først, da en sammenslutning af muslimske organisationer, efter klager til Østersøkommissæren for menneskerettigheder, flere ministeriers indgriben og en del politisk strid, fik lov til at købe og indrette deres egen begravelsesplads i Brøndby syd 
for København. Siden indvielsen af denne begravelsesplads i 2006 har der været relativt stille om muslimske begravelser i Danmark.

At den offentlige debat er tonet ud, gør dog ikke fænomenet mindre aktuelt i en dansk integrationsdebat. For det faktum, at et stigende antal muslimske indvandrere i dag vælger at lade sig begrave i Danmark, ${ }^{1}$ kombineret med at den muslimske gravplads i Brøndby kun er en blandt flere mulige begravelsessteder for muslimer her i landet, giver nye muligheder for at undersøge muslimske indvandrere og efterkommeres tilknytning til Danmark og de forskellige måder, muslimsk identitet kommer til udtryk på i en dansk kontekst. Valg af begravelsesplads er nemlig ikke blot et spørgsmål om at skaffe de jordiske rester af afdøde af vejen; det er også et rum, der på forskellig vis iscenesætter den enkeltes død, afdødes relation til forskellige fællesskaber og forholdet mellem levende og døde, og derigennem udsiger noget om tilhørsforhold og identitetsdannelse blandt minoriteter i Danmark.

Døden og det rum, den foregår i, kan analyseres fra forskellige perspektiver religiøse, rituelle, symbolske, følelsesmæssige, etc. - men har altid en materiel dimension. Det gælder ikke blot det fysiske sted, hvor afdøde begraves, men også de mange genstande, der tjener til at mindes den døde: billeder og fotoalbum, særlige ejendele, som afdøde var knyttet til, udsmykning af gravsted, gravstenens form og indskrift, m.m. Både rum og genstande indgår i den måde, afdøde og efterladte iscenesætter døden og afdøde på, og kan således betragtes som ytringer, der udsiger noget om tilhørsforhold og identitet. Og sådanne ytringer angår ikke alene givne og opnåede fællesskaber som slægtskab, ægteskab og profession, men også valgte fællesskaber og de værdier og normer, der ligger til grund for disse. ${ }^{2}$

En sådan materiel tilgang til døden og de døde ligger i god forlængelse af Taylors teori om, at døden ikke blot kan ses som et problem i form af tab og brudt kontinuitet, men også som en mulighed, der kan bidrage til at fremme sociale, kulturelle og politiske mål. ${ }^{3}$ Ved at dreje perspektivet på døden fra problem til mulighed gøres døden som fænomen mere dynamisk og bliver en velegnet optik til at afdække sociale og identitetsmæssige træk, der kan udsige noget om minoriteters tilknytning til majoritetskulturen, og hvordan denne udvikler sig over tid.

Med udgangspunkt i en forståelse af døden som mulighed og med fokus på den materielle dimension af døden skal jeg i det følgende undersøge muslimske indvandreres valg af sidste hvilested - de mulige valg af begravelsessteder i Danmark og de materielle betingelser, der kendetegner disse - med det formål at indkredse en række markører, der kan udsige noget om tilhørsforhold og identitetsdannelse blandt muslimer i Danmark. I det følgende skal jeg først gøre rede for det teoretiske begrebsapparat, der anvendes i analysen af muslimers valg af sidste

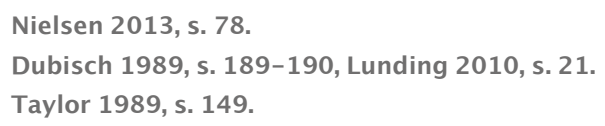


hvilested i Danmark, herunder Ruggs taksonomi for begravelsespladser (2000), eller det hun selv kalder "a common grammar" for "a language of different burial space types", samt begreberne territorialisering, sakralisering og sekularisering. Derefter sættes det sidste hvilested ind i et immigrantperspektiv, og der gives en karakteristik af de forskellige typer af gravpladser, der står til rådighed for muslimer i Danmark. Det følges af en redegørelse for den udvikling, der er sket i udbuddet af gravpladser, eksemplificeret ved tre eksempler fra hhv. Odense og Københavnsområdet. Artiklen afsluttes med en sammenlignende analyse af to gravpladser fra samme geografiske område, der illustrerer det valg, muslimer må foretage i forbindelse med begravelse i Danmark, og hvordan dette valg kan tolkes mht. markering af identitet og tilhørsforhold.

\section{Det sidste hvilested som materiel ytring}

At se menneskers sidste hvilested som materiel ytring omfatter i hvert fald to aspekter af det fysiske rum, som begravelsesstedet er indlejret i: Stedets placering og dets indretning. Når stedet spiller en central rolle her, skyldes det bl.a., at migration netop er karakteriseret ved, at mennesker flytter sig fra et sted til et andet, hvilket afføder det følelsesmæssige spørgsmål, som migrant-tilværelsen overalt i verden medfører: "Hvor er hjemme?” Dette stedsdilemma aktualiseres yderligere ved livets afslutning, for her får valg af begravelsessted en definitiv dimension: Eftersom nationale lovgivninger og religiøse traditioner kun i meget sjældne tilfælde tillader at grave de fysiske rester af et lig op og genbegrave det et andet sted, lader valget sig ikke uden videre lave om. Fredningstiden for grave i Danmark er fx ved lov fastsat som mindst 20 år, ${ }^{4}$ og der gives kun i ganske særlige tilfælde tilladelse til at genåbne grave og flytte lig. ${ }^{5}$ Det betyder i praksis, at valg af begravelsesplads får et iboende træk af permanens og derved kommer til at fremstå som antitesen til de mange transitrum, som ellers præger vor tids globaliserede samfund - lufthavne, togstationer, supermarkeder m.m. - der både "undviger og udjævner identitet”, og hvis arkitektur og indretning har til formål at udviske oplevelsen af permanens. ${ }^{6}$

Et sted lader sig ikke definere alene som geografisk lokalitet, men har både en fysisk og en mental dimension: Begrebet fungerer på én gang som fysisk rum og tankefigur og spænder over både geografisk position, materiel form og betyd-

4 Bekendtgørelse af lov om folkekirkens kirkebygninger og kirkegårde, § 13. Fredningstiden er dog kun 10 år for urnegrave, men da kremering ikke er tilladt $\mathrm{i}$ islam, har denne regel ingen betydning for muslimer.

5 Der kan i ganske særlige tilfælde gives forhåndsgaranti til flygtninge, der opholder sig i Danmark, om at en afdød "på et senere tidspunkt, når forholdene i hjemlandet gør det muligt, kan blive flyttet til en grav i hjemlandet." Vejledning om flytning af lig og urner.

6 Bille og Flohr Sørensen 2012, s. 84-85. 
nings- og værdisted, og det lader sig vanskeligt reduceres til enten det ene eller det andet. ${ }^{7}$ Begravelsespladser kan således ikke reduceres til et sted, der udelukkende har til formål at skaffe sig af med de jordiske rester af afdøde, men er tillige et lokus for sorg, savn, erindring, genealogisk tilhørsforhold m.m., og materialiserer derigennem en kompleksitet af informationer af både personlig, social og religiøs art. Det sidste hvilested kan således beskrives som et eksempel på en territorialiseringsproces i den forstand, at det materialiserer en tilknytning til et konkret sted (afklaring af stedsdilemma), der er karakteriseret ved permanens i kraft af sin forankring i jorden, og som tilskrives betydning og værdi i form af tingsliggørelse af sociale og religiøse relationer og spændinger.

Også et steds indretning kan tjene som materiel ytring. For at forstå, hvordan det fungerer mht. det sidste hvilested, kan man med fordele anvende Ruggs taksonomi for begravelsespladser, der netop har til formål at skabe grundlag for komparative, multidisciplinære og tværkulturelle studier af begravelsesrummet, ${ }^{8}$ og her opererer hun med fire kategorier, der er indbyrdes forbundne. Den første kategori beskriver gravpladsers fysiske karakteristika: Hvor ligger gravpladsen i forhold til bebyggelse og anden menneskelig aktivitet, hvordan afgrænses den i forhold til omgivelserne, og hvordan markeres indgange til pladsen? Hvordan er gravstederne placeret i forhold til hinanden og til eventuelle religiøse bygninger, hvordan er de enkelte gravsteder indrettet, og hvilke materialer kan og må anvendes? Og hvilke informationer kan afkodes af gravstens formmæssige, sproglige og billedmæssige udtryk ${ }^{9}$ De fysiske karakteristika ved gravplads og gravsted skaber på en gang grundlag for sammenligninger på tværs af tid og rum og materialiserer sociale og religiøse relationer og spændinger. ${ }^{10}$ Ruggs anden kategori har fokus på ejerforhold og ejerskab: Ejes gravpladsen af sekulære eller religiøse institutioner, forvaltes den i offentligt eller privat regi, og i hvor høj grad har brugerne/ de pårørende ejerskab til stedet? Ejerforhold og ejerskab indskriver derved gravpladser i det omgivende samfunds økonomiske og politiske strukturer og kaster lys på magtforhold og autoritet, såvel internt som i forhold til omgivende aktører. Ruggs tredje kategori angår begravelsesrummets markering af individuel hhv. kollektiv identitet: På hvilken måde spiller fysiske karakteristika, sproglige markører (på gravsten, gennem skiltning, mm.) og ejerforhold og ejerskab sammen i udtryk, der materialiserer bestemte opfattelser af fællesskab over for individ, trossamfund over for omgivende samfund, minoritet over for majoritet? Og som fjerde kategori fokuserer Rugg på sakralisering af begravelsesrummet, som afhængig af trossam-

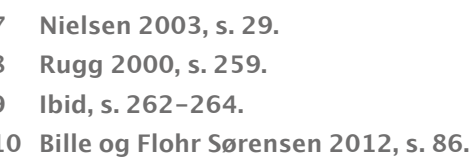


fund, aktører etc. kan finde sted gennem tilstedeværelse af religiøse bygninger, i kraft af særlige ritualer, gennem det omgivende samfunds respekt, etc. ${ }^{11}$

Hvor de tre første kategorier af Ruggs taksonomi uden videre lader sig anvende i en analyse af muslimske indvandreres sidste hvilested i Danmark qua deres klare materielle fokus, kræver sakraliseringsdimensionen en yderligere afklaring: For selv om Rugg er opmærksom på, at religiøse minoriteter ikke blot bruger gravpladser til at begrave deres døde, men også til at markere identitet, overser hun, hvordan netop sakralisering kan anvendes til at markere forskelle. ${ }^{12}$ For at forstå denne dynamik kan man med fordel bruge Kopelowitz' forklaringsmodel (2003), der anskuer det sakrale som et fænomen, der netop materialiseres i kontakten med den sekulære offentlige sfære. Det er således først i mødet med det sekulære, at mennesker fra traditionelle før-moderne samfund bliver bevidste om deres religiøsitet, og derfor lader sakralisering sig ikke forstå uden henvisning til sekularisering. ${ }^{13}$ Mennesker, der lever i sekulære samfund, og som ønsker at bevare kontakten til det religiøse, må således vende sig mod religiøse institutioner og ved hjælp af de ritualer og symboler, som disse institutioner har etableret og sanktioneret, finde redskaber til at etablere og bevare denne kontakt. Religiøse institutioner, i praksis forvaltet af et præsteskab, har derfor to distinkte opgaver i et sekulært samfund: Dels at etablere og forvalte religiøse ritualer og symboler, som giver folk mulighed for at identificere hinanden som medlemmer af et trossamfund og derved kunne skelne mellem insidere og outsidere i den sekulære offentlige sfære. Dels at sikre, at disse symboler og ritualer giver mening i en sekulær virkelighed, så folk ikke forlader trosfællesskabet, hvilket nødvendiggør en vis grad af diversitet og inklusion. Men hvor første opgave forudsætter en hierarkisk autoritet, der kan tydeliggøre, hvilke ritualer og symboler der er legitime, og hvordan de skal bruges, forvaltes den anden opgave bedst gennem en mere egalitær form for autoritet. ${ }^{14}$ Derfor må religiøse institutioner i sekulære samfund forstå at balancere hensigtsmæssigt mellem hierarkiske og egalitære autoritetsformer, hvis de vil eksistere: Hvis de egalitære bliver for stærke, forsvinder forskellen mellem dem, der tilhører trossamfundet, og dem, der ikke gør, og hvis hierarkiske autoritetsformer omvendt vinder overhånd, kan trossamfundet ikke længere absorbere den forskellighed, der netop er karakteristisk ved sekulære samfund. ${ }^{15}$

Autoritetsformer lader sig materialisere på forskellig vis i forbindelse med gravpladser og -steder i sekulære samfund: Religiøse mindretal kan således markere sakralisering gennem brug af religiøse ritualer og symboler, der både adskiller sig fra andre trossamfund og fra det omgivende sekulære samfund, ved $\mathrm{fx}$ at

11 Rugg, s. 261-264 og 272.

12 Ibid., s. 267.

13 Kopelowitz 2003, s. 86-87.

14 Ibid., s. 97-98.

15 Ibid., s. 98-99. 
indrette gravpladser efter andre principper end majoritetens, anvende specifikke materialer til gravsteder og bruge religiøse symboler og sproglige udtryk på gravsten, der understreger religiøs forskellighed. Omvendt kan religiøse mindretal vælge at materialisere egalitære autoritetsformer ved at nedtone brug af religiøse ritualer og symboler i forbindelse med gravpladser og -steder, så de i højere grad kommer til at ligne dem, der kendes fra det omgivende sekulære samfund. Jeg skal i det følgende således anvende begrebet sakralisering som et udtryk for en optoning af religiøse forskelle, mens sekularisering betegner en nedtoning af religiøse ritualer og symboler, så de i højere grad ligner dem, der anvendes i det omgivende sekulære samfund.

\section{Det sidste hvilested i et migrantperspektiv}

I traditionelle samfund er det almindeligt at sætte lighedstegn mellem "hjem” og det sted forfædrene er begravet - et fænomen, der både kan forklare de store familiegravsteder på danske kirkegårde, og at mange muslimske indvandrere vælger at lade sig begrave i hjemlandet. ${ }^{16}$ Denne forståelse af hjem bygger på en forestilling om, at mennesker er forankret i jord, at de i abstrakt forstand har rødder, der knytter dem følelsesmæssigt til denne jord, og, når døden indtræder, tildeler den afgørende betydning for, hvor deres sidste hvilested skal placeres. Denne forestilling har ændret sig i takt med industrialisering og indvandringen til byerne: For når transport bliver billigere og mennesker mere mobile, lever mange mennesker flere forskellige steder i løbet af et liv, og dør også andre steder end der, hvor forfædrene er begravet. Denne udvikling har medført, at de fleste mennesker i dag begraves i nærheden af det sted, de sidst har boet, hvilket igen betyder, at den fædrene jord ikke længere spiller samme symbolske rolle som tidligere.

Med globaliseringen og øgede muligheder for mobilitet har valget af sidste hvilested fået ny betydning. Det mobile liv betyder nemlig, at mennesker typisk etablerer tilknytning til flere steder i løbet af et liv, og det afspejler sig i stigende grad i valget af sidste hvilested: For mennesker holder ikke nødvendigvis op med at være mobile, bare fordi de er døde, men lader sig gerne transportere til et sidste hvilested, som har særlig betydning for dem eller deres efterladte, også selvom det ligger andre steder end i nærheden af sidste bolig. Det kan fx være en gravplads i nærheden af et elsket sommerhus eller en tidligere bolig, et sted der repræsenterer en skelsættende begivenhed i livet, eller et særligt naturskønt område. Og post-mortal mobilitet er en sektor i vækst: En undersøgelse af fænomenet i Sverige fra 2010 viste, at "the mobility rate among the deceased is higher than permanent migration among the living, and has increased significantly in 
the past decade or so". ${ }^{17}$ Det til trods for, at prisen for transport af døde er to til tre gange højere end transport af levende. ${ }^{18}$ Den sidste rejse kommer derved til at repræsentere den ultimative tilknytning til et sted, hvor den døde kan stedes til hvile efter et langt liv i bevægelse. ${ }^{19}$ Så fra at se det sidste hvilested som et hjem, der naturligt er knyttet til den jord, hvor forfædrene ligger begravet, er valget af gravsted blevet et personligt anliggende, som ikke kun afhænger af sidste bopæl, men også kan tage form af et aktivt tilvalg, der iscenesætter døden som både individuel og intim. ${ }^{20}$

Muslimske immigranter i Danmark står principielt med samme valg som alle andre, når de skal beslutte sig for et sidste hvilested: at vende tilbage til den fædrene jord i oprindelseslandet, lade sig begrave i nærheden af sidste bopæl i Danmark, eller foretage et aktivt tilvalg af et fjernereliggende sted, der har særlig følelsesmæssig betydning. I praksis er valget dog mere komplekst: Dels er konsekvenserne af at lade sig begrave i oprindelseslandet større pga. de betydelige transportomkostninger, der er knyttet til dette ønske. Dels indebærer valget af gravplads i nærheden af sidste bolig en risiko for, at de ritualer og traditioner, som muslimer forbinder med død og begravelse, ikke lader sig overholde i en dansk kristen kontekst. Hertil kommer så den konflikt, som førstegenerationsindvandrere ofte står i mellem den følelsesmæssige tilknytning til familie og sociale netværk i oprindelseslandet og ønsket om at blive begravet i nærheden af børn og familie i det nye land. I den optik får valget af sidste hvilested uundgåeligt karakter af valg af fællesskab og dermed også valg af tilhørsforhold.

For muslimske indvandrere der vælger at lade sig begrave i Danmark, såvel som for den store gruppe af muslimske flygtninge i Danmark der af politiske grunde ikke kan vende tilbage til deres oprindelsesland, opstår der endnu et spørgsmål mht. valg af sidste hvilested. Ikke blot skal der vælges mellem en begravelsesplads i nærheden af sidste bosted og et fjernere liggende gravsted med særlig følelsesmæssig tilknytning. Der skal også tages stilling til i hvert fald tre forskellige typer af begravelsespladser med hver deres institutionelle forankring og religiøse hhv. sekulære identitet: Kirkegårde i traditionel forstand, kommunale kirkegårde og private begravelsespladser.

\section{Traditionelle, kommunale og private kirkegårde i Danmark}

"Kirkegård" er den almindelige betegnelse for det sted, vi i Danmark begraver de døde, hvad enten de er kristne eller tilhører andre trosretninger. Det er fx almin-

17 Marjavaara 2012, s. 271.

18 Ibid., s. 258.

19 Ibid., s. 256.

20 Ibid., s. 259. 
deligt at tale om jødiske kirkegårde, mens "begravelsesplads" eller "gravplads" på dansk synes at være reserveret til det sted, muslimer begraver deres døde. Denne sprogbrug er dog hverken konsekvent eller transparent. Bag ordet "kirkegård” gemmer sig desuden to forskellige betydninger, som på flere europæiske sprog benævnes forskelligt: churchyard eller graveyard, der i sit udtryk vægter sammenhængen mellem kirke og begravelsesplads og således understreger det religiøse aspekt af rummet, versus det engelske cemetery og det franske cimetière af det græske Koimeterion, der betyder "det store soveværelse” og altså ikke har nogen religiøs konnotation. ${ }^{21}$ Jeg skal nedenfor bevare en skelnen mellem (kristne) kirkegårde og (muslimske) gravpladser og tillige i mangel af et passende dansk ord for cemetery sondre mellem traditionelle og kommunale kirkegårde.

En kirkegård i traditionel forstand er en gravplads, der er vokset frem omkring en kirke, som ofte har været beliggende centralt, fx i forhold til et by- eller landsbysamfund. Trods den evangelisk-lutherske kirkes status som statskirke, er jorden principielt ejet af kirken og administreres og forvaltes af et valgt menighedsråd. En kirkegård er som regel afgrænset fra omgivelserne af en mur, et hegn eller en hæk, der dels markerer adskillelsen mellem de levende og de døde, dels sikrer, at de døde ikke forstyrres af upassende aktiviteter, og indgange markeres med låger, der ofte angiver formålet med rummet. ${ }^{22}$ Det faktum, at kirkegården er vokset frem omkring en kirke, har betydning for dens form og indretning. Kirkegårde er organiseret, så det er muligt at finde frem til det ønskede gravsted gennem et net af stier, og større kirkegårde er som regel inddelt i forskellige rum med interne afgrænsninger i form af hække eller stier. Gravstederne er ofte placeret i et centrum periferi forhold til kirken. Således er gravsteder for bedrestillede familier og afdøde med høj social status typisk begravet i nærheden af kirken, ved hovedindgangen eller langs vejen op mod kirkens indgang, mens ubemidlede og socialt mindre velstillede traditionelt er begravet i periferien. ${ }^{23}$ Stedet sakraliseres bl.a. gennem en religiøs afsmitning fra kirke til kirkegård. Når kirken, forstået som "Guds hus", hvor der løbende foregår gudstjenester og andre religiøse ritualer, udgør centrum for kirkegården, og den tillige ligger på religiøst indviet jord, sker der en "helliggørelse" af kirkegårdsrummet. ${ }^{24}$

Fra midten af 1700-tallet blev det nødvendigt at finde nye jordlodder, der kunne aflaste de traditionelle kirkegårde, især i de voksende bysamfund. Disse "assisterende” kirkegårde, eller hjælpekirkegårde, som de benævnes i lovtekster, blev typisk anlagt i zonen mellem by og land, men er siden vokset sammen med de ekspanderende bysamfund..$^{25} \mathrm{Og}$ med assistens kirkegårdene opstår den moderne

21 Sommer 2003, s. 93.

22 Rugg 2000, s. 262.

23 Ibid., s. 265.

24 Rugg 2000, s. 266.

25 Sommer 2003, s. 261-262. 
storbykirkegård, der på flere måder adskiller sig fra de traditionelle kirkegårde: De er som traditionelle kirkegårde underlagt folkekirkens religiøse og administrative retningslinjer, men jorden er typisk kommunalt ejet og administreres af kommunale vej og park-forvaltninger. Jordlodderne er generelt store - Vestre Kirkegård i København er som den største på 540.000 m². Vestre Kirkegård i Århus (fra 1927) på $440.000 \mathrm{~m}^{2}$ - og til forskel fra de traditionelle kirkegårde er der ingen kirker på disse kirkegårde, højest et kapel, som ofte er bygget efter indvielsen og ikke nødvendigvis kun bruges til begravelser, men også til kulturelle arrangementer, udstillinger o.lign.

Fraværet af kirken som centrum for disse hjælpekirkegårde samt det kommunale ejerskab har betydning for deres indretning og religiøse status. Som nyanlagte jordlodder er de typisk indrettet med lange lige alléer, et overskueligt stisystem og velafgrænsede afdelinger, der gør det let at finde frem til et ønsket gravsted. Der er principielt ingen center-periferi opdeling set i forhold til et religiøst eller landskabsarkitektonisk centrum, ${ }^{26}$ om end hovedindgangen ofte udgør et centralt omdrejningspunkt. Begravelsesrummet sakraliseres således ikke gennem kirkebygninger, men nok gennem den sproglige omtale af rummet som "kirkegård" i modsætning til det ikke-religiøse cemetary/cimetière. Det kommunale ejerforhold betyder desuden, at disse kirkegårde skal betjene alle borgere, også ikke-kristne - noget, lokale menighedsråd i princippet kan afslå, hvis afdøde ikke bor i sognet. ${ }^{27}$ Der er da også oprettet særlige afdelinger for forskellige trosretninger og interessegrupper på disse kirkegårde. Således har Assistens kirkegård i København fx en særlig regnbue-afdeling for bøsser og lesbiske, en større gravplads til medlemmer af en motorcykel-klub og en afdeling for hjemløse. Vestre Kirkegård i København har særafdelinger for muslimer, færinger og grønlændere, og Assistens kirkegård i Odense en afdeling for Asa-troende.

Ud over de traditionelle og kommunale kirkegårde, som udgør langt størstedelen af de godkendte begravelsespladser i Danmark, har nogle få trossamfund etableret egne kirkegårde. Det drejer sig om Mosaisk Trossamfund, Den Reformerte Kirke i Fredericia og Brødremenigheden i Christiansfeld, der alle havde ret til at drive egne kirkegård, før der blev indført religionsfrihed med grundloven i 1849, samt nogle enkelte evangelisk-lutherske frimenigheder, der har fået kirkeministeriets tilladelse til at anlægge kirkegårde i forbindelse med deres kirker. ${ }^{28} \mathrm{Ud}$ over ministerielle tilladelser kræver etablering af egne kirkegårde først og fremmest betydelige ressourcer. Trossamfundet skal selv finansiere jordkøbet, betale anlægsudgifter og stille sikkerhed for, at det kan vedligeholde og administrere området i en årrække fremover. Derfor er det heller ikke overraskende, at folkekirken indtager en dominerende plads i Danmark, når det gælder kirkegårde og

26 Sommer 2004, s. 230.

27 Bekendtgørelse af lov om folkekirkens kirkebygninger og kirkegårde,§14, stk. 2 og 3.

28 Ministeriet for Ligestilling og Kirke: Kirkegårde uden for folkekirken. 
begravelser: I 2012 fik 87 \% af alle der døde i Danmark en folkekirkelig begravelse eller bisættelse, mens det i 2011 og 2010 var $88 \% .{ }^{29}$ Hertil skal lægges de begravelser og bisættelser, der blev foretaget på folkekirkens kirkegårde, men uden deltagelse af en folkekirkelig præst.

Med folkekirkens dominerende stilling på begravelsesområdet kan det ikke overraske, at det affødte en del offentlig debat, da en gruppe muslimske indvandrere i midten af 1990'erne begyndte at lede efter et egnet sted, der kunne anvendes til begravelse af muslimer. Etableringen af særlige muslimske begravelsespladser, der kan tilgodese de anderledes døds- og begravelsesritualer som kendes i islam, var et klart brud med folkekirkens næsten enerådige monopol på begravelser.

\section{Muslimske afdelinger på danske kirkegårde}

For de muslimske indvandrere, der kom til Danmark fra 1960'erne og frem, var det i mange år kutyme at sende afdøde til oprindelseslandet for at blive begravet. Der findes ingen tilgængelige statistiske opgørelser over, hvor mange muslimer i Danmark der over årene har valgt denne løsning, men Jonker angiver, at 89 \% af alle muslimske indvandrere i Europa blev transporteret til hjemlandet for at blive begravet i begyndelsen af 1990'erne, og der er ingen grund til at antage, at Danmark skulle adskille sig væsentligt fra disse tal. ${ }^{30}$ Siden er antallet faldet betydeligt, omend flertallet af muslimer stadig vælger at blive begravet i oprindelseslandet. En opgørelse fra Dansk Islamisk Begravelsesfond viste, at ca. 60 \% valgte denne løsning i 2011. ${ }^{31}$ Men selvom tallene er usikre, er der næppe tvivl om tendensen: Dels er en del af de ca. 236.000 muslimer, der bor i Danmark, ${ }^{32}$ politiske flygtninge og kan eller ønsker ikke at blive begravet i det land, de kommer fra, dels er omkostningerne ved transport til oprindelseslandet betydeligt større end at begrave afdøde i Danmark. En begravelse i et mellemøstligt land kan let koste 50.000 kr., med mindre der er tegnet en begravelsesforsikring. ${ }^{33}$ Hertil kommer, at yngre generationer af muslimer typisk føler sig mere knyttet til Danmark end deres forældre, og derfor sandsynligvis vil vælge at blive begravet her, samt at børn og børnebørns tilknytning til Danmark må formodes at være en fastholdelses-faktor for den ældre generations valg af begravelsessted. I takt med at den demografiske fordeling af muslimske indvandrere og efterkommere

\footnotetext{
29 Ministeriet for Ligestilling og Kirke: Kirkelige begravelser.

30 Jonker 1996a, s. 162.

31 Kristeligt Dagblad 12/5/2012, s. 1.

32 Jacobsen 2012, s. 176. Antallet af muslimer i Danmark er estimeret, da danske myndigheder ikke registrerer religiøst tilhørsforhold. Se også Jacobsen 2007 for en diskussion af opgørelsesmetoder. 33 Jyllandsposten 24/6/2005, s. 4.
} 
kommer til at ligne den danske, vil antallet af døde gradvis stige fra de ca. 350 muslimske dødsfald, Islamisk Begravelsesfont angav i 2011, til ca. 2300 årligt, og der er al mulig grund til at formode, at et stigende antal af disse vil ønske at blive begravet i Danmark. ${ }^{34}$

Som alle andre har muslimer ret til at blive begravet i det sogn, de bor i, og da de fleste muslimer typisk har bosat sig i nærheden af de større byer, ${ }^{35}$ er det først og fremmest her, vi finder muslimske gravsteder. ${ }^{36}$ I takt med, at antallet af muslimske begravelser langsomt voksede op igennem 1980'erne og 90'erne, blev der oprettet særlige afdelinger for muslimer på udvalgte kirkegårde, og det har i praksis medført, at muslimer, der ønskede at blive begravet i Danmark, som regel har fravalgt en begravelse i nærheden af sidste bopæl til fordel for den nærmeste kirkegård med muslimsk afdeling. Der er næsten ingen enkeltstående muslimske gravsteder på de danske kirkegårde, selv ikke i bydele med mange muslimske indbyggere. De er i stedet koncentreret på en eller to kirkegårde eller begravelsespladser i eller omkring en større by.

Korsløkke kirkegård i Odense er et eksempel på, hvordan en muslimsk afdeling er vokset frem på en traditionel kirkegård. Kirkegården ligger bag Vor Frelsers Kirke, er etableret i 1908, kirken er indviet i 1909 og det første muslimske gravsted er dateret 1980. Den muslimske afdeling er placeret i yderkanten af kirkegården langs en befærdet vej længst mulig væk fra kirken og hovedindgangen. Der er ingen egentlig indgang til afdelingen, ingen skiltning der viser vej til gravpladsen, og det er først, når man kommer ind bag en høj hæk, det bliver tydeligt, at der ligger en muslimsk afdeling: Her ligger gravsten med arabiske indskrifter, islamiske symboler samt et "fatiha" - navnet på åbnings-suraen i Koranen - placeret øverst på gravstenen. Afdelingen er opdelt i et sydligt afsnit med 30 grave, der dækker perioden fra 1980 til april 1994, og et nordligt med 127 grave der dækker den efterfølgende periode. Placeringen af gravstederne falder i tre faser: De første fire grave i det sydlige afsnit, der dækker perioden 1980-84, ligger i østvestlig retning med gravstenen i østlig ende, ${ }^{37}$ mens de efterfølgende 26 grave ligger i lige rækker nord for disse på hver side af nogle græsstier, der løber fra øst mod vest, og med front mod hinanden, sådan som det også kendes fra den øvrige kirkegårdskultur. I afdelingens nordlige afsnit er de afdøde placeret i enkeltræk-

34 Ca. 1\% af den danske befolkning dør om året. Med ca. 236.000 muslimer i Danmark svarer dette til omkring 2360 døde årligt, under forudsætning af at den demografiske fordeling af muslimer nærmer sig den danske.

35 Danmarks statistik 2012, s. 17.

36 Et gravsted er her defineret som muslimsk, hvis det enten er placeret på en gravplads med anknytning til islam eller gennem indskrifter (navn, symboler, sprog eller lign.) markerer tilhørsforhold til islam.

37 Begravelsesretning og placering af sten indikerer, at disse første muslimer er begravet, så de ser mod vest og dermed væk fra kirken, der ligger på den østlige side af kirkegården. Denne begravelsesretning bryder også med tidligere kristne traditioner for at begrave de døde med ansigtet mod øst for at kunne se Kristi genopstandelse (Fjord Jensen 2002, s. 13). 


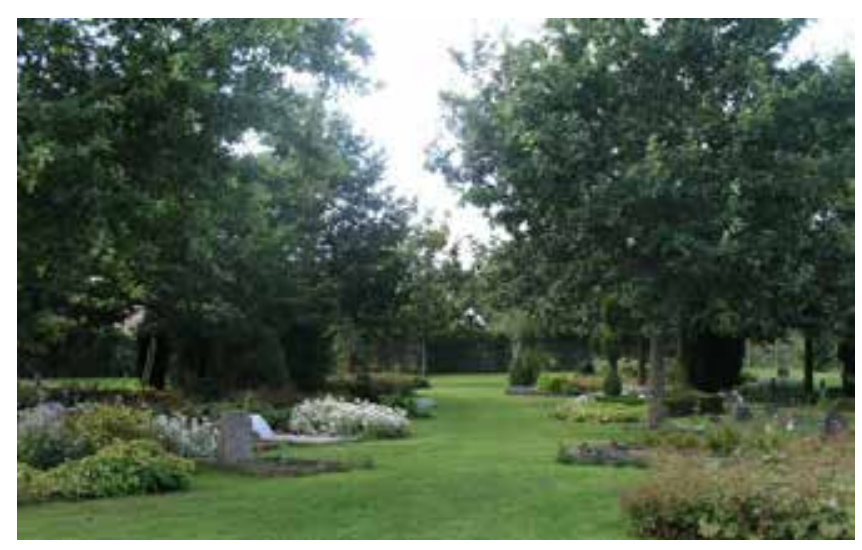

Muslimsk afsnit (nordlig del) på Korsløkke kirkegård i Odense. Foto: Helle Lykke Nielsen, 2012.

ker i overensstemmelse med islamiske forskrifter om, at afdøde skal begraves på højre side med ansigtet vendt mod Mekka og gravsten traditionelt placeret ved hovedet.

De muslimske grave på Korsløkke består med få undtagelser af enkeltgrave afgrænset af en kant af marmor, brosten, mursten, cementsten eller en lav hæk, og de er typisk dækket af lyse småsten eller beplantning. Gravsten er enten opretstående plader på max $40 \mathrm{~cm}$ eller liggende sten af meget varierende kvalitet: fra flotte marmorsten med guldskrift over forvitrede betonsten med utydelig skrift til plastikplader og laminerede billeder. Indskrifterne er på forskellige sprog med enten latinske eller arabiske bogstaver og angiver typisk navn, fødsels- og dødsdato, evt. fødested samt en række religiøse standardformuleringer. Til gengæld er der næsten ingen familiemæssige eller sociale markeringer - kun en enkel gravsten markerer fx profession. Trods gravstenenes varierende kvalitet er det samlede udtryk således relativt ensartet og neddæmpet.

Et andet eksempel på, hvordan muslimske afdelinger er vokset frem på danske kirkegård, finder vi på Vestre kirkegård i København. Som primær kommunal begravelsesplads for muslimer i hovedstaden frem til 2006, hvor den islamiske begravelsesplads i Brøndby åbnede, er den langt større end Korsløkke. Her ligger 1156 muslimske grave fordelt på fire afdelinger: to større og en lille nyanlagt afdeling, der alle er placeret i udkanten af kirkegården i det diametralt modsatte hjørne af hovedindgangen samt et mindre afsnit i den sydlige del af kirkegården. Fælles for afsnittene er, at alle grave ligger i øst-vestlig retning: I det ældste afsnit, der åbnede i 1976, ligger gravstederne placeret langs stier med front mod hinanden, ganske som kristne kistegrave på den øvrige del af kirkegården, mens gravene i de øvrige afsnit ligger i lige rækker med hovedet mod vest og "blikket” rettet mod øst. Ingen steder tages der således hensyn til islamiske principper om at begrave de døde med ansigtet vendt mod Mekka. Begrundelsen herfor skal ikke findes i pladsmæssige forhold: Vestre Kirkegård har rigelig plads til at indrette afdelinger med særlige plads- eller indretningsbehov, for kun 10.000 af de 45.000 


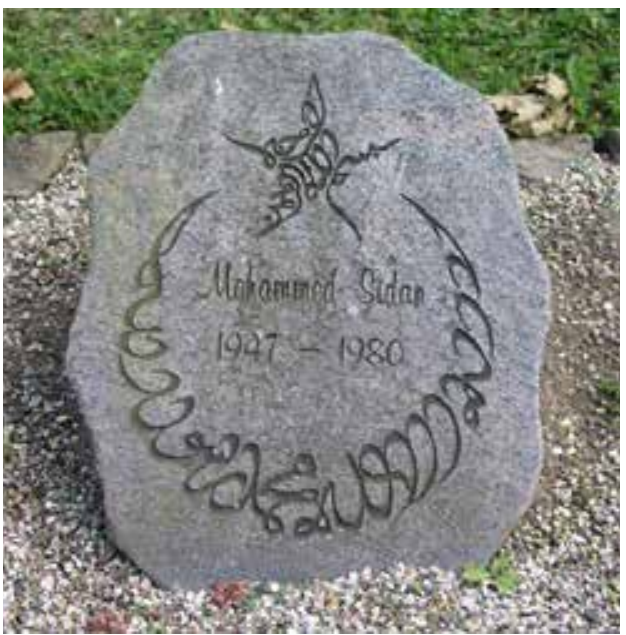

Det første muslimske gravsted på Korsløkke kirkegård i Odense, dateret 1980. Graven ligger øst-vest med gravstenen placeret mod øst, så den døde "kigger" mod vest. I den øverste stjerneformede indskrift står der på arabisk: "I guds, den nådiges, den barmhjertiges navn". Den cirkelformede kalligrafi omkring afdødes navn, fødsels- og dødsdato anfører den muslimske trosbekendelse: "Der er ingen anden gud end gud, og Muhammed er hans profet". Stenen er designet af afdødes svigersøn, der har medbragt kalligrafien fra Irak. Foto: Helle Lykke Nielsen, 2012.

individuelle begravelsespladser, som kirkegården kan rumme, er i dag fyldt op. ${ }^{38}$ De fire muslimske afdelinger er i lighed med andre afdelinger på kirkegården omgivet af lave hække, der markerer en visuel afgrænsning mod de omgivende afdelinger, men en af afdelingerne er kun afgrænset på tre sider - den fjerde står åben mod et område med kristne grave og en særafdeling for Frelsens Hær. Og så er alle fire muslimske afdelinger anlagt i områder, hvor der i forvejen ligger ældre kristne grave, og det betyder i praksis, at nogle muslimske grave ligger side om side med kristne. Det drejer sig dog ikke om noget stort antal - der er i alt 40 kristne grave på de fire afdeling. Selvom de fleste muslimske grave ligger i udkanten af kirkegården, er de alligevel synlige i kirkegårdsrummet: Informationstavler og gratis brochurer markerer de muslimske afdelinger på et kort, og flere steder er der opsat skilte, der med pile angiver retningen mod "Muslimsk afdeling”.

De enkelte muslimske gravsteder er ligesom på Korsløkke kirkegård kantet med forskellige sten eller lave hække og dækket af småsten eller plantet til med blomster. En del grave er desuden pyntet med stearinlys, lanterner, afskårne blomster og små figurer - fugle, engle, hjerter, hænder med religiøse indskrifter o. lign. Gravstenenes form og indskrifter varierer betydeligt, fra enkle cementplader med utydelig indskrift over opretstående glatslebne stenplader med messingbogstaver til store spejlblanke granit og marmorsarkofager, der dækker hele gravstedet. Der er gravsten med indgraveret landkort over Iran, hjerteformede gravsten med indgraverede blomster, høje gravsten med søjler og monumentalt udtryk, og billeder af afdøde, præget i sten eller metal. Indskrifterne er skrevet med latinske eller arabiske bogstaver og angiver som på Korsløkke typisk navn, fødsels- og dødsdato samt, for ca. 1/3 vedkommende, religiøse formuleringer eller symboler som fx "haj/haja” (religiøs titel for muslimer der har foretaget pilgrimsrejse til Mekka), "al-fatiha" eller påkaldelse af Allah og hans profet Muhammad - sidst-

38 Center for Kirkegårde, udateret, s. 3. 


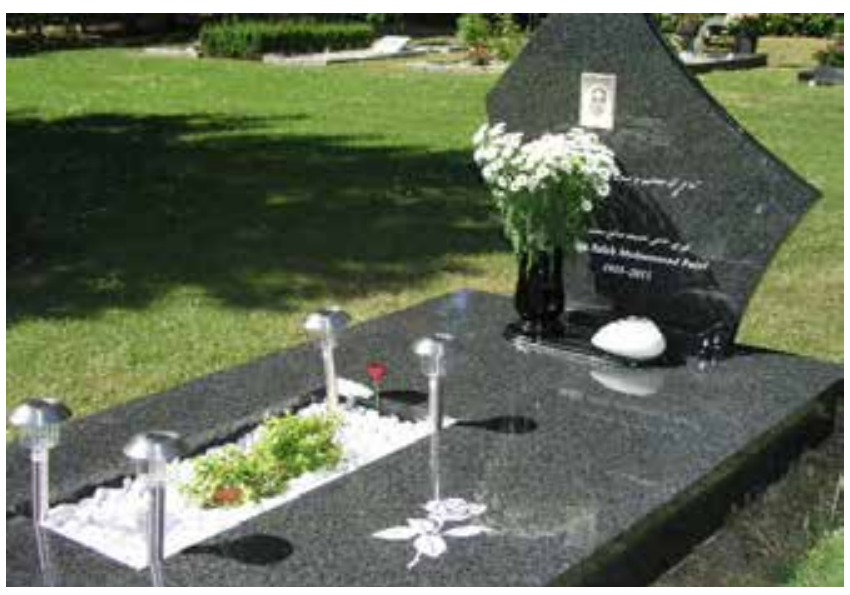

Gravsten på Vestre Kirkegårds muslimske afdeling 16. Foto: Helle Lykke Nielsen 2013.

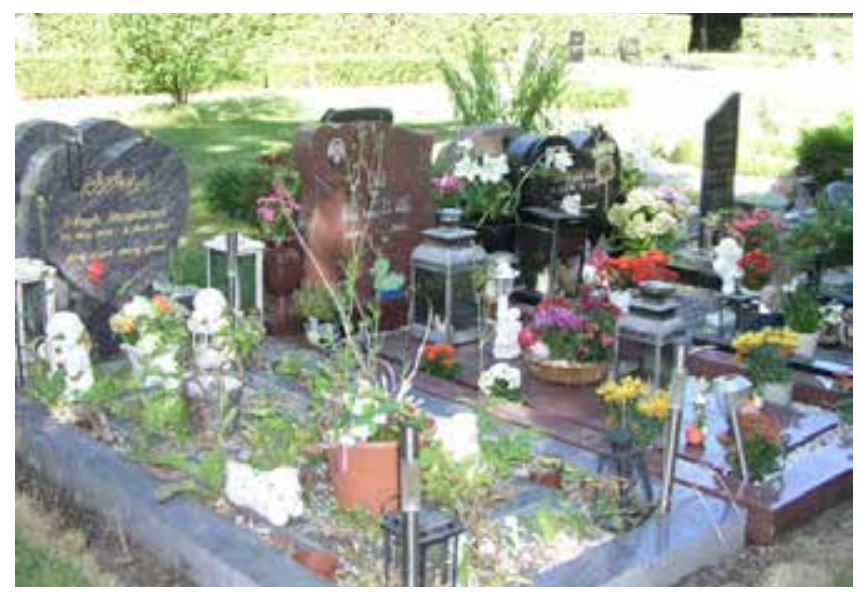

Engle, lys, lanterner, billeder og perleplader udsmykker nogle af de muslimske grave på Vestre kirkegård. Foto: Helle Lykke Nielsen 2013.

nævnte typisk på et mellemøstligt sprog (arabisk, persisk, tyrkisk, urdu). Mange gravsten har familiemæssige markeringer - "kære far", "mor, mormor og farmor", "baby og lillesøster" - og følelsesmæssige udtryk som "dyrebare”, ”vi elsker og savner dig”, "højt elsket, dybt savnet”, typisk på dansk. Der er næsten ingen sproglige markeringer af social status; til gengæld er de store sarkofaglignende marmorgravsten med guldindskrift en tydelig markør for social status. Der er således langt større variation i både form og sprogligt udtryk mellem de muslimske gravsteder på Vestre kirkegård, end det er tilfældet på Korsløkke kirkegård.

\section{Dansk Islamisk begravelsesplads i Brøndby}

Fra det blev kendt i offentligheden i midten af 1990'erne, at en gruppe muslimer ønskede at etablere en muslimsk gravplads i Danmark, til købet af jorden 
i Brøndby var en realitet i december 2004, gik der ca. 10 år. ${ }^{39}$ At det tog så lang tid, skyldtes i første omgang en kombination af muslimske ønsker om, at begravelsespladsen skulle ligge i rimelig køreafstand fra København, og afvisning fra en række kommuner, der i medierne henviste til lokalplaner og andre tekniske barrierer, når jordlodder i deres område kom på tale. Også indbyrdes uenigheder blandt forskellige nationaliteter af muslimer om de betingelser, begravelsespladsen skulle fungere efter, synes at have spillet en rolle. ${ }^{40}$ Det var først, da initiativtagerne i september 2000 klagede til Østersørådets kommissær for menneskerettigheder, Ole Espersen, som sendte henvendelsen videre til Statsministeriet, at der kom skred i sagen: I løbet af efteråret 2000 fandt et udvalg under Kirkeministeriet et velegnet område under Skov- og Naturstyrelsen, og da det samtidig lykkedes 20 muslimske organisationer at blive enige om at oprette en forening med vedtægter og fælles bestyrelse, der kunne fungere som forhandlingspartner, var optimismen stor. ${ }^{41}$ Men sagen udviklede sig derefter til en politisk strid, først på kommunalt plan og siden i folketinget: Jorden lå nemlig i Brøndby Kommune, men var ejet af Københavns Kommune, og borgmesteren i København, Jens Kramer Mikkelsen (S), krævede som udgangspunkt 20-22 millioner for grunden, mens Brøndbys borgmester Kjeld Rasmussen (S) mente, at den kun var 700.000 kr. værd. ${ }^{42}$ I september 2001 blev der endelig fundet et kompromis: Hvis en uafhængig vurdering viste, at grundens værdi oversteg tre millioner kroner, hvilket var det beløb, muslimerne havde stillet som købsgaranti, ville staten kompensere Københavns Kommune for beløbet over de tre millioner og på den måde sikre, at de muslimske organisationer kunne erhverve jorden. ${ }^{43}$ Kirkeminister Johannes Lebech (KF) havde imidlertid ikke sikret sig finansudvalgets opbakning, og det fik Dansk Folkeparti til at kræve sagen op i Folketinget i et forsøg på at få stoppet det statslige tilskud til begravelsespladsen og - muligvis - trække tiden ud til et kommende folketingsvalg. ${ }^{44}$ Med den nye V-K regerings tiltrædelse i januar 2002, hvis parlamentariske grundlag blev hentet hos Dansk Folkeparti, blev al tale om statslig kompensation, som indirekte kunne komme de muslimske organisationer til gode, umuliggjort, og det var først efter en indsamling af flere penge og yder-

39 Ønsket om en muslimsk gravplads opstod som en udløber af diskussionerne om anerkendelse af islam som officielt trossamfund i Danmark, se fx Berlingske Tidende 10/6/1994 og 20/11/1995, Politiken 8/1/1996. For køb af gravpladsen, se Tv2nyhederne 11/12/2004.

40 Det socialdemokratiske medlem af Københavns Borgerrepræsentation, Hamid El Mousti, der var en af initiativtagerne til projektet, udtalte flere gange til medierne, at det var et stort problem at muslimer ikke stod samlet i denne sag: "Folk er mere styret af deres nationaliteter end af deres tro, og vi har svært ved at blive enige hen over nationaliteterne", Weekendavisen 9/1/ 1998. Se også "Muslimerne i åben strid om gravplads", Berlingske Tidende 22/12/1998.

41 Berlingske Tidende 23/10/2000.

42 Jyllandsposten 23/5/2001. Se også Kristeligt Dagblad 18/1/2002.

43 Berlingske Tidende 31/8/2001.

44 Berlingske Tidende 5/11/2001. 
ligere forhandlinger om en række teknikaliteter, at handelen omsider gik i orden i december 2004.

Begravelsespladsen i Brøndby åbnede officielt i 2006. Den ejes, administreres og vedligeholdes af Dansk Islamisk Begravelsesfond, en samling af 23 muslimske foreninger i Danmark, og dækker et område på 50.000 m2, hvoraf de 32.000 m2 må anvendes som gravpladser. Pladsen ligger som en kile mellem Holbækmotorvejen mod syd, Brøndbyskoven mod vest, Hvidovre psykiatriske hospital mod nord og en ganske smal tilkørsel fra Brøndbyøstervej mod øst, og har plads til 4000-5000 grave, ${ }^{45}$ hvoraf 653 var i anvendelse i juli 2013. Indgangen ligger tilbagetrukket fra vejen, er markeret af en stor sten med teksten "Dansk Islamisk Begravelsesfond, Muslimsk begravelsesplads, indviet 22. 9 2006” og en jernport med islamisk mønster, og først i sommeren 2013 er der opsat et skilt ved vejen med teksten "Muslimsk begravelsesplads”, der gør forbipasserende opmærksom på gravpladsens eksistens.

Fire ting adskiller grundlæggende muslimske gravpladser fra den dominerende kirkegårdskultur i Danmark: De anlægges ikke i tilknytning til nogen moske, pladsen skal indrettes, så det er muligt at placere den døde på højre side med ansigtet vendt mod Mekka, gravstederne må ikke sløjfes, men skal ligge til evig tid, og de døde må ikke brændes. Disse træk har betydning for gravpladsernes indretning: I modsætning til kirkegårde, hvor grave placeres i et centrum-periferi forhold til kirke og hovedindgang, er muslimske gravpladser oftest organiseret kronologisk efter dødsdato, således at gravstederne placeres i lange lige rækker med de dødes ansigt vendt mod Mekka. Her er som udgangspunkt ingen afdelinger, ${ }^{46}$ og begravelsesrummet sakraliseres primært gennem religiøse markører på gravsten i form af religiøse symboler og skriftsteder; også begravelser af døde, der har været på pilgrimsrejse til Mekka og derfor anfører "haj /haja” på gravstenen, tilfører pladsen sakral kapital. ${ }^{47}$

Gravpladsen i Brøndby følger ovenstående retningslinjer. Den er anlagt på en stor græsmark med en tilkørselsvej, der gennemskærer pladsen fra øst mod vest og med en stor parkeringsplads af grus, der fungerer som ankomst- og ceremoniplads foran de lige anlagte rækker af grave. De enkelte gravsteder på pladsen er som udgangspunkt kantet med lys granit og dækket af lyse småsten med en plade, en gravsten (med indskrift) eller en natursten (uden indskrift) ved afdødes hoved. På nogle få gravsteder er der plantet blomster, andre har krukker med plastikblomster eller små buketter, men langt de fleste gravsteder fremstår alene med granitkant, lyse småsten og en gravplade. Det skaber et meget ensartet udtryk, hvilket utvivlsomt er tilsigtet, eftersom retningslinjerne for begravelsespladsen angiver, at der ”ikke (må) sættes billeder, stearinlys, mad, drikkevarer, bamser el- 


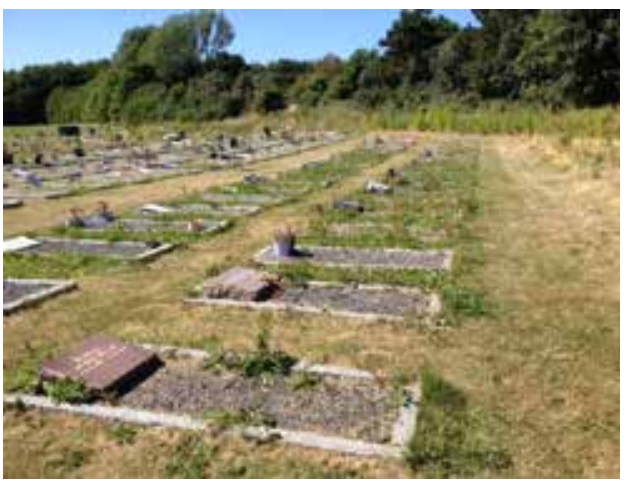

Den muslimske begravelsesplads i Brøndby. Foto: Helle Lykke Nielsen, 2013.

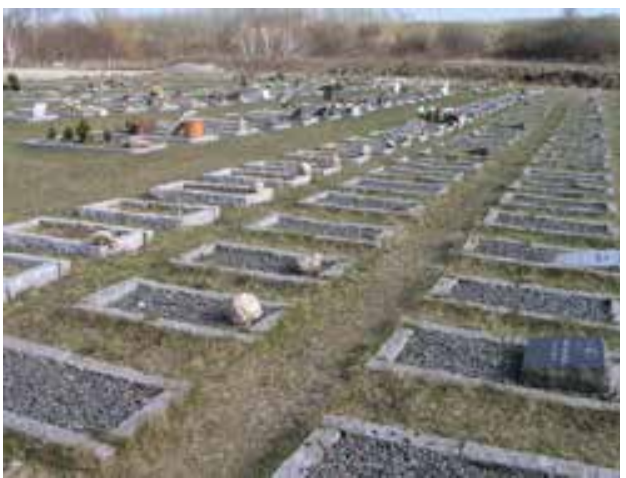

Tre rækker af børnegrave på den muslimske gravplads i Brøndby. Også aborter begraves ifølge islamisk gravskik. Foto: Helle Lykke Nielsen 2013.

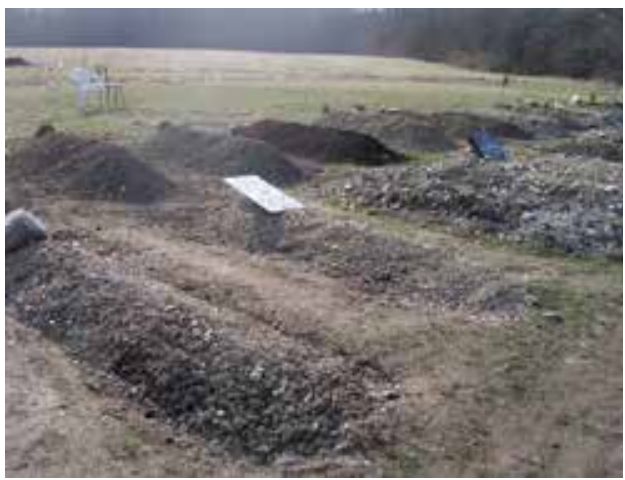

Nyanlagte grave i den nordlige del af Brøndby begravelsesplads. Kant- og dæksten anlægges efter mindst et år. Foto: Helle Lykke Nielsen 2013.

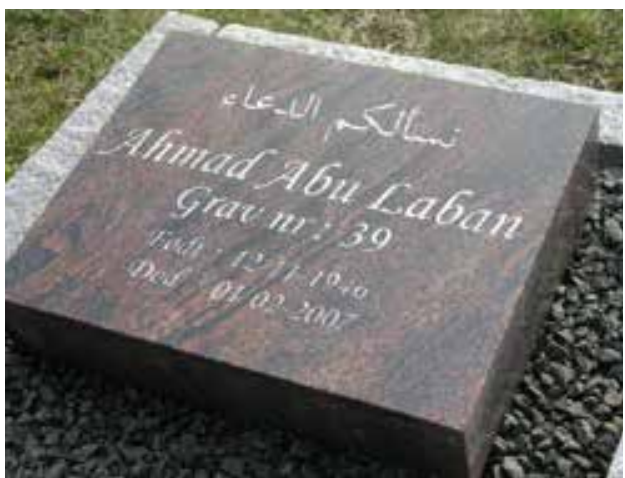

Imam Abu Labans grav på gravpladsen i Brøndby. Øverst på gravstenen står der med arabiske bogstaver "Vi beder jer om (at fremføre) en du'a-bøn". Foto: Helle Lykke Nielsen 2013.

ler lignende på graven”, ligesom der heller ikke må tændes lys eller bygges oven på graven "hverken huse, rum, små vægge eller forhøjninger". ${ }^{48}$

Også gravstenenes form og indskrifter er relativt ensartede: Det er typisk hvide, grå eller sorte firkantede plader i marmor, granit eller plastik, de fleste ikke højere end 40-50 cm. Nogle har form af en bog som symbol på koranen, og enkelte er hjerteformede, typisk på grave for børn og unge. Udsmykningen er sparsom, om end man kan finde sten med indgraverede billeder af Ka'baen i Mekka eller dekoreret med duer, roser og billeder af afdøde. Indskrifterne er skrevet med latinske eller arabiske bogstaver og angiver som på de øvrige kirkegårde typisk navn, fødsels- og dødsdato. Og så har næsten alle sten en religiøs markør, enten i form af "al-fatiha", en påberåbelse af Allah og hans profet, et skriftsted eller sætningen nas'alkum al-du'a (vi beder jer (om at fremføre) en du'a-bøn) med arabiske bog- 
staver - en formulering, man hverken finder på Korsløkke eller Vestre kirkegård. Mens stort set alle religiøse markører er skrevet med arabiske bogstaver, er de relativt få familie- og følelsesmæssige udtryk - "vor elskede mand og far”," du vil altid være i vore hjerter" etc. - helt overvejende skrevet på dansk eller engelsk. ${ }^{49}$ Gravsteder og gravsten er således karakteriseret ved stor ensartethed både i form og sprogligt udtryk, og dette kombineret med begravelsespladsens beliggenhed på den flade græsmark, de lave gravsteder og den sparsomme beplantning, der giver frit udsyn over hele pladsen, skaber et samlet udtryk af begravelsesrummet som nedtonet, uniformt og præget af en kølig ro.

\section{Muslimsk identitet i Danmark: Sakralisering eller sekularisering?}

For muslimer, der begraves i Danmark, synes der at være en tydelig præference for at blive stedt til hvile på en gravplads med anknytning til islam, dvs. enten i en muslimsk afdeling på en traditionel eller kommunal kirkegård eller på den muslimske begravelsesplads i Brøndby. Det ses klart af det faktum, at der kun findes ganske få muslimske gravsteder på kirkegårde uden for de etablerede muslimske afsnit, fx i og omkring de store byer, hvor de fleste muslimer bor. Et sådant valg af muslimsk gravfællesskab kan tolkes både religiøst og socialt: Det kan skyldes et ønske om at sikre sig en begravelse, der så vidt mulig overholder islamiske principper for derved at opnå den adgang til livet efter døden, som islamiske tekster foreskriver; ${ }^{50}$ eller det kan være et ønske om at tydeliggøre sit tilhørsforhold til islam over for omgivelserne, hvad enten det gælder familie, andre muslimer eller det danske samfund som helhed. ${ }^{51}$

I nogle af de større danske byer er det muligt at vælge mellem flere begravelsespladser med særlig tilknytning til islam, typisk muslimske afdelinger på enten kommunale eller traditionelle kirkegårde. Det er fx tilfældet i Odense, hvor kommunen i 2002 supplerede den muslimske afdeling på Korsløkke kirkegård med et nyt muslimsk afsnit på den nærliggende kommunale Rising kirkegård. Begge afdelinger opfylder i dag de islamiske forskrifter om, at afdøde skal begraves med ansigtet vendt mod Mekka, men hvor Korsløkkes muslimske afdeling er placeret perifert og ganske usynligt i kirkegårdsrummet og signalerer kollektiv identitet gennem brugen af relativt ensartede gravsteder og en klar afgrænsning til den øvrige del af kirkegården, bærer den muslimske afdeling på Rising kommunale kirkegård tydelig præg af at være islamisk i kraft af sit åbne landskab med

49 Persiske gravsten synes i et vist omfang at være en undtagelse herfra; flere af disse har indgraveret digte på persisk med følelsesmæssige udtryk.

50 Se Halevi 2007; Smith og Haddad, 1981; Starkey 2009.

51 Ansari 2007, s. 562. 
lave hække og tydelige religiøse markeringer på gravsten, der varierer betydeligt i både størrelse, form og materialer. Den udviskning af muslimsk identitet, der finder sted på Korsløkke, er selvsagt ikke befordrende for oplevelsen af ejerskab, og det er derfor heller ikke overraskende, at det kun er ganske få muslimer - 11 i alt - der har ladet sig begrave i denne afdeling efter åbningen af den muslimske afdeling på Rising. ${ }^{52}$

Med etableringen af den muslimske begravelsesplads i Brøndby i 2006 fik muslimer i København for første gang et reelt valg mellem at lade sig begrave i overensstemmelse med islamiske forskrifter eller på en kommunal kirkegård med muslimske afdelinger. En optælling af gravsteder fra september 2006, hvor indvielsen af gravpladsen i Brøndby fandt sted, viser, at der frem til juli 2013 blev begravet 233 muslimer på Vestre Kirkegård mod 653 i Brøndby. Det reelle tal for Vestre Kirkegård er dog i praksis højere: Optællingen på Vestre kirkegård omfatter de gravsten, der eksplicit angiver en dødsdato efter september 2006, mens de muslimske grave der alene er dekoreret med natursten uden indskrift eller slet ingen sten har - det gælder især, men ikke kun, børnegrave - ikke er talt med, da de ikke kan datobestemmes. I modsætning hertil er alle grave i Brøndby, inkl. dem uden gravsten og med gravsten uden indskrift, inddraget i opgørelsen. Optællingen viser desuden, at antallet af muslimske grave på Vestre Kirkegård er svagt stigende gennem perioden: fra oktober 2006 til 2008 blev der begravet 64 muslimer på Vestre kirkegård, for 2009-2010 var tallet 71 og for perioden 2011 august 2013 var tallet 98.

Hvorfor omkring 2/3 af de muslimer, der har valgt at lade sig begrave i Københavnsområdet siden 2006, har valgt gravpladsen i Brøndby, mens 1/3 har valgt den kommunale Vestre Kirkegård, lader sig ikke alene besvare gennem en analyse baseret på materialitet: Måske er der familiemæssige bånd til den ene eller den anden gravplads, økonomi kan spille en rolle, ${ }^{53}$ ligesom der kan eksistere religiøs uenighed med den eller de grupper, som tegner betingelserne for begravelsespladsen i Brøndby. ${ }^{54}$ Men ser vi på valg af sidste hvilested som materiel ytring, træder der et tydeligt mønster frem. For begravelsespladsen i Brøndby gælder det nemlig, at den homogene brug af materialer for de enkelte gravsteder og gravsten og de stramme regler for brug af blomster og andre dekorative elementer på gravstederne skaber et meget ensartet udtryk, der signalerer kollektiv identitet på bekostning af individualitet. Samtidig betyder de mange og tydelige religiøse markeringer på gravsten - herunder det for begravelsespladsens helt særegne

52 For en analyse af det muslimske afsnit på Rising Kirkegård, se Nielsen 2013.

53 Anlæggelsen af et typisk muslimsk gravsted med kant- og perlesten på Vestre Kirkegård koster ca. $12.600 \mathrm{kr}$. inkl. gravning af graven, hvortil skal lægges udgifter til kiste, transport, afholdelse af højtidelighed m.m. Som medlem af Dansk Islamisk Begravelsesfonds begravelsesforsikring dækkes alle disse udgifter for et indmeldelsesgebyr på 200 kr. og en årlig afgift på mellem 100 $150 \mathrm{kr}$.

54 Se Jonker 1996b, s. 38 for lignende overvejelser blandt tyrkiske immigranter i Berlin. 
udtryk "Nas'alkum al-du'a" - kombineret med nedtoningen af følelsesmæssige, sociale og til en vis grad familiemæssige markeringer, at der lægges vægt på religiøse aspekter frem for sociale. Det religiøse aspekt understreges yderligere af, at princippet med enkeltgrave i kronologisk rækkefølge håndhæves så konsekvent, at det ikke længere er muligt at bestille gravpladser, så ægtepar eller børn kan begraves ved siden af hinanden. ${ }^{55}$ Noget, der ellers er muligt på mange muslimske gravpladser i fx Mellemøsten. Ved således at understrege kollektiv identitet frem for individualitet og religiøsitet frem for sociale og følelsesmæssige udtryk, iscenesættes døden her som tilstræbt ensartet, upersonlig og kollektiv og understreger i sit udtryk, at alle muslimer er lige i døden. Der er med andre ord tale om en høj grad af sakralisering, der gør det muligt at skelne mellem dem, der tilhører trossamfundet, og dem der ikke gør.

I modsætning til begravelsespladsen i Brøndby er de muslimske afdelinger på Vestre kirkegård karakteriseret ved stor variation i materialevalg for både gravsted og gravsten, og familie og pårørende benytter sig i udstrakt grad af dekorative elementer på gravstedet i form af blomster, dukker, lys og andre personlige genstande. Det giver et varieret fysisk udtryk, der tydeligt signalerer individualitet frem for kollektivitet. Gravstenenes varierende former og størrelser og deres inskriptioner med primært følelsesmæssige og familiære udtryk og i mindre grad religiøse, viser, at der lægges vægt på sociale aspekter frem for religiøse, hvilket også understøttes af forekomsten af en række fint forarbejdede store og dyre gravsten i bekostelige materialer. De muslimske afdelinger på Vestre Kirkegård er tillige mindre klart afgrænsede i forhold til de omliggende kristne gravsteder, end det fx gælder på Korsløkke Kirkegård, i kraft af lave hække og åbne stisystemer, og nogle steder forsvinder grænserne mellem kristne og muslimske grave helt, således at de to rum smelter sammen. Ved således at understrege individuel identitet frem for kollektivitet og sociale og følelsesmæssige aspekter frem for religiøse og tillige nedtone afgrænsningen i forhold til de omgivende kristne gravsteder iscenesættes døden her som mere personlig, intim og sekulariseret. Derved følger disse muslimske afdelinger den tendens til mere individualiserede gravsteder, som også kendes fra moderne kristen kirkegårdskultur, ${ }^{56}$ og det giver således mening at tale om en høj grad af sekularisering, der tenderer mod at gøre det sværere at skelne mellem dem, der tilhører det muslimske trossamfund, og dem der ikke gør.

Materiel analyse udsiger noget om, hvad folk gør, ikke hvad de siger de gør, og i den forstand er det sidste hvilested som materiel ytring en klar markering af, at muslimer i Danmark signalerer tilhørsforhold til majoriteten på i hvert fald to måder: I valget af sidste hvilested vender de sig enten mod dansk islamisk begra-

55 Der ligger dog et tomt gravsted ved siden af imam Abu Labans grav, som formodes at være reserveret til hans kone. Personlig kommunikation med inspektøren for gravpladsen, juli 2013.

56 Mohr 2013, s. 83; Wansele 2008, s. 176-177. 
velsesforening, der som religiøs institution forvalter ritualer og symboler gennem hierarkisk autoritet, der iscenesætter døden som tilstræbt ensartet, upersonlig og kollektiv og dermed understreger lighed i døden, en klar fælles identitet og en distinkt afgrænsning i forhold til majoritetssamfundets begravelseskulturer. Eller de vender sig mod det sekulære samfunds tilbud om begravelsessted, hvor ritualer og symboler forvaltes gennem en mere egalitær autoritet, der sætter friere rammer for udfoldelse i form af familiegravsteder, mulighed for at signalere socioøkonomisk velstand, høj grad af individualitet og inddragelse af træk fra dansk begravelseskultur, og derved markerer en højere grad af tilhørsforhold til en sekulariseret dansk begravelseskultur.

\section{Konklusion}

At lade sig begrave i Danmark i stedet for i oprindelseslandet signalerer tilhørsforhold. Ikke nødvendigvis til den danske nation, men måske først og fremmest til de familiære og sociale netværk i det nye land. Mens dette valg primært er aktuelt og konfliktuelt for førstegenerations indvandrere, synes der at være høj grad af konsensus blandt muslimer på tværs af generationer om at vælge et gravsted i Danmark med tydelig anknytning til islam, hvad enten det er et muslimsk afsnit på en traditionel eller kommunal kirkegård eller den muslimske gravplads i Brøndby. Dette valg identificerer dem som tilhængere af islam over for omverden og skaber samtidig et religiøst og kulturelt fællesskab, der både fungerer som et visuelt og rumligt udtryk for muslimsk tilstedeværelse i Danmark og som symbolsk markør for deres status som religiøst mindretal.

Der synes desuden at udkrystallisere sig to tendenser i den muslimske begravelseskultur i Danmark, som kommer til udtryk der, hvor muslimer har et reelt valg mellem flere begravelsespladser: enten at lade sig begrave på en muslimsk ejet begravelsesplads, der markerer forskellighed over for majoritetssamfundet og derigennem udtrykker og bekræfter en klart afgrænset religiøs identitet. Eller at vælge et muslimsk afsnit på en kommunal kirkegård, og dermed lade sig begrave i en majoritetskontekst, hvor individuelle, sociale og religiøse forskelle tydeliggøres, og hvor grænserne til majoritetskulturen er mere flydende. De to tendenser illustrerer derved forskellige måder at være dansk muslim på. Men uanset valget er det stigende antal muslimer, der lader sig begrave i Danmark på gravpladser med tydelig islamisk identitet et udtryk for, at muslimer er i færd med at skabe sig et rum her i landet, at de så at sige territorialiseres og dermed tager et første skridt mod en ny forankret identitet i Danmark. Derved bliver de forskellige muslimske gravpladser og -steder et eksempel på et integrationsrum, der skaber et nyt hjem for de døde, deres pårørende og sandsynligvis for kommende generationer. Muslimer er med andre ord i færd med at slå rødder i Danmark, og det foregår gradvis, 
i stilhed og uden den turbulens, som ellers ofte præger den offentlige debat om muslimske indvandrere.

\section{Litteraturliste}

Ansari, Humayun 2007: "Burying the dead: making Muslim space in Britain”. Historical Research 80, s. 545-566.

Bekendtgørelse af lov om folkekirkens kirkebygninger og kirkegårde, https:// www.retsinformation.dk/Forms/R0710.aspx?id=123330

Berlingske Tidende 10/6/1994, sektion 1, s. 4. ”Kulturkløft på landets kirkegårde”.

Berlingske Tidende 20/11/1995, sektion 1, s. 12. "Halvmåne over byen”.

Berlingske tidende 22/12/ 1998, sektion 1, s. 2. "Muslimerne i åben strid om gravplads".

Berlingske Tidende 23/10/2000, sektion 1, side 2. "Islamisk forsoning”.

Berlingske Tidende 31/8/2001, sektion 1, s. 6. ”Muslimsk gravplads på plads”.

Berlingske Tidende 5/11/2001, sektion 1, s. 6. "Valg stopper muslimsk gravplads".

Bille, Mikkel og Flohr Sørensen, Tim 2012: Materialitet. En indføring i kultur, identitet og teknologi. København, Samfundslitteratur.

Center for Kirkegårde, Københavns kommune, udateret: Vestre Kirkegård. http://kk.sites.itera.dk/apps/kk_pub2/pdf/486_Vestre_Kirkegaard_2008.pdf (juli 2013)

Danmarks Statistik 2012: Indvandrere i Danmark 2012. www.dst.dk/publ/indvandrereidk (juli 2013)

Dansk Islamisk Begravelsesfond, http://dibf.dk/index.php/om-gravpladsen (juli 2013)

Dansk Islamisk Begravelsesfond, ordensreglement, http://dibf.dk/index.php/ ordensreglement (juli 2013)

Dubisch, Jill 1989: ”Death and social change in Greece.” Anthropological Quarterly, 64: 4, s. 189-200.

Fjord Jensen, Johan 2002: Vest for paradis. Begravelsespladsernes natur. Gyldendal.

Francis, Doris, Leonie Kellaher and Georgina Neophytou 2005: Secret Cemetery. Berg Publishers.

Halevi, Leor 2007: Muhammad’s Grave. Death Rites and the Making of Islamic Society. Columbia University Press.

Jacobsen, Brian Arly 2007: ”Muslimer I Denmark - en kritisk vurdering af antalsopgørelser”. Margit Warburg og Brian Jacobsen (red.): Tørre tal om troen. Religionsdemografi i det 21. århundrede. Univers, s. 143 - 165. 
Jacobsen, Brian Arly 2012: ”Denmark”. Jørgen B. Nielsen et al. (eds.): Yearbook of Muslims in Europe, vol. 4. Brill, s. 175-192.

Jonker, Gerdien 1996a: “The many facets of Islam. Death, dying and disposal between orthodox rule and historical convention”. Pittu Laungani (ed.): Death and Bereavement Across Cultures. Routledge, s. 156-174.

Jonker, Gerdien 1996b: “The knife's edge: Muslim burial in the diaspora”. Mortality 1: 1, s. 27-43.

Jyllandsposten 23/5/2001, s. 3. ”Gravplads: Nyt slagsmål om muslimsk gravplads".

Jyllandsposten 24/6/2005, s. 4. "De danske pakistanere: Begravelse. Danske muslimer forsikrer den sidste rejse"

Kopelowitz, Ezra 2003: "Negotiating with the secular: Forms of religious authority and their political consequences”. Arthur Grail and David Bromley (eds.): Defining Religion: Investigating the Boundaries between the Sacred and Secular. JAI, Elsevier Science, s. 85-106.

Kristeligt Dagblad 18/1/2002, debat. "En politisk motiveret forsinkelse”.

Kristeligt Dagblad 12/5/2012, s. 1. "Flere muslimer vil begraves i Danmark".

Lunding, Gitte 2010: "Kirkegårdskulturen og det levede liv”. Kulturcentret Assistens: Midt i verden i 250 år. Assistens 1760-2010. Kulturcentret Assistens.

Marjavaara, Roger 2012: "The final trip: Post-mortal mobility in Sweden”. Mortality 17: 3, s. 256-275.

Ministeriet for Ligestilling og Kirke: Kirkegårde uden for folkekirken http:// miliki.dk/kirke/publikationer/vejledninger/begravelseforalle/kirkegaardenbegravelsesplads-for-alle/kirkegaarde-uden-for-folkekirken/ (juni 2013)

Ministeriet for Ligestilling og Kirke: Kirkelige begravelser, http://miliki.dk/ kirke/statistik/kirkelige-begravelser/ (juni 2013)

Mohr, Monika 2013: "Tre kommunale kirkegårde i Aalborg Kommune”. Landskab nr. 3, s. 82-85.

Nielsen, Helle Lykke 2013: "Den sidste rejse”. Landskab nr. 3, s. 78-81.

Nielsen, Niels, K. 2004: Steder i Europa. Aarhus, Aarhus University Press.

Politiken 8/1/1996, Kultursektionen s. 1. "Islam vil slå rødder i Danmark”.

Reimers, Eva 1999: "Death and identity: graves and funerals as cultural communication”. Mortality 4: 2, s. 147-166.

Reimers, Eva 2001: ”Cemeteries and Cemetery Reform”. Glennys Howarth and Oliver Leaman (eds.): Encyclopedia of Death and Dying. Routledge, http://www.deathreference.com/Bl-Ce/Cemeteries-and-Cemetery-Reform. html\#ixzz2TMiANaQi

Rugg, Julie 2000: "Defining the place of burial: What makes a cemetery a cemetery?”. Mortality 5: 3, s. 259-275.

Smith, Jane Idleman and Haddad, Yvonne Yazbeck 1981: The Islamic Understanding of Death and Resurrection. State University of New York Press. 
Sommer, Anne-Louise 2003: De dødes haver. Syddansk Universitetsforlag.

Sommer, Anne-Louise 2004: "Mellem tradition og fornyelse”. Kirkegårdskultur. Årsskrift for Kirkegårdskultur, s. 34-43.

Starkey, Janet 2009: " Death, Paradise and the Arabian Nights”. Mortality 14: 3, s. 286-302.

Taylor, Lawrence J. 1989: "Introduction: The uses of Death in Europe”. Anthropological Quarterly 62: 4, s. 149-154.

Tv2nyhederne, 11/12/ 2004. "Muslimer betaler begravelsesplads". http://nyhederne.tv2.dk/article.php/id-1681905:muslimer-betaler-begravelsesplads.html (juli 2013)

Vejledning om flytning af lig og urner https://www.retsinformation.dk/Forms/ R0710.aspx?id=113565

Wansele, Janet Ferrari 2008: "Fleksibilitet vs. normativitet - om institutionaliseringens indflydelse på danske og religiøse minoriteters begravelsesskikke”. Michael Hviid Jacobsen og Mette Haakonsen (red.): Memento Mori - døden i Danmark i tværfagligt lys. Syddansk Universitetsforlag, s. 174-189.

Weekendavisen, 9/1/ 1998, sektion 1, s. 5. ”I hænderne på et monopol”.

\section{English Summary}

Today an increasing number of Muslims choose to be buried in Denmark. The article analyses Muslims' choice of a last resting-place in Denmark as a material statement with the aim of uncovering social and identity-related features that can tell us something about the links of minorities with the majority culture. First an account is given of the theoretical conceptual apparatus used in the analysis, including Rugg's taxonomy for burial sites (2000) and the concepts of territorialization, sacralization and secularization. Subsequently the last resting-place is viewed in an immigrant perspective, and it is argued that Muslim migrants' choice of burial place in Denmark is more complex than that of non-migrants, among other reasons because decisions must be made on at least three different types of burial site, each with its own institutional rooting and religious or secular identity. Then comes a characterization of the different types of burial site available to Muslims in Denmark, exemplified by three instances from Odense and the Copenhagen area. With a point of departure in physical characteristics of cemeteries and grave plots in the form of location, furnishings, form and linguistic expression, as well as ownership, sacralization and collective versus individual identity, an analysis is conducted of the Muslim section of Korsløkke Cemetery in Odense, the Muslim sections of the municipal Vestre Kirkegård cemetery in Copenhagen and Denmark's only privately owned Muslim cemetery, the Danish- 
Islamic Burial Foundation in Brøndby. The analysis identifies two tendencies in Muslim burial culture, a sacralizing and a secularizing tendency, which come to expression where Muslims have a genuine choice between several burial sites, and concludes that Muslims in Denmark are tacitly in progress with a territorialization process which is taking place entirely without the turbulence otherwise often typical of public debate on Muslim immigrants. 